\title{
THE REASONS OF THE HEART
}

\section{KAROLINA WIGURA, WYNALAZEK NOWOCZESNEGO SERCA. FILOZOFICZNE ŹRÓDŁA WSPÓŁCZESNEGO MYŚLENIA O EMOCJACH}

Agata Lukomska

University of Warsaw

We live in emotional times. Go to any news site, open a newspaper, turn on your TV, and you will see story after story about hate, fear, envy and contempt - but also enthusiasm and hope - bringing people to the streets in mass protests, toppling goverments, fuelling populist policies, creating fertile ground for fake news and driving fanatics to commit violent acts. How we got here is hardly a mystery. The profound geopolitical, social and cultural changes in the world of the last decades, accelerated by the rise of the Internet and in particular of social media, have resulted in a perceived, if not real, erosion not only of great narratives, but of rational communication as such, with its central notions of truth and objective facts. Emotions are taking over, which many observe with alarm. Others, however, point out that it need not be bad news. Authors like Bethany Albertson and Shana Kushner Gadarian (Anxious Politics: Democratic Citizenship in a Threatening World, 2015), Ted Brader (Campaigning for Hearts and Minds: How Emotional Appeals in Political Ads Work, 2006) or William Davies (Nervous States: How Feeling Took. Over the World, 2018) are cautiously optimistic. Emotions, they suggest, are the raw material of social life, and as such they are a source of conflict - but they can also be our way out of it. Exactly because they are primordial, they are universal and easily communicable. Our political de- 
bate always appealed to emotions - now that it's breaking down, shouldn't we simply go with our feelings?

There was a moment in the history of moral philosophy when emotions became, similarily, the focus of all attention. They had always been present in the background, of interest to ethicists as regular but rarely reliable (in fact, frequently cumbersome) companions of moral reasoning. But the arrival of logical positivism saw them take centre stage. In 1936 Alfred Ayer, the young disciple of the thinkers of the Vienna Circle, published his first book Language, Truth, and Logic, which introduced the English-speaking world to the Viennese positivist programme - and spelled out its consequences for all the areas of inquiry the positivists deem unscientific. Since logical positivism defines facts as what can be verified by the senses, there are, from its point of view, no religious, esthetic or moral facts, so there can be no scientific thinking in these matters, and in fact, no rational argument about them. In the case of morality, that leaves us with emotions as the only point of reference for our judgments; according to Ayer and other emotivists, moral utterances have no truth-value - they can be neither right nor wrong. They are nothing more than expressions of our feelings.

There is a price to pay for such elegance. Even at the peak of its popularity, emotivism had to continue to fend off the charge of promoting relativism or even moral nihilism. But subjectivism does not, of course, equal relativism, and the work of later emotivists spelled out how moral views, even if they are reducible to simple emotions, can be effectively discussed and reflected upon, how they can come to be questioned and reformed. For a moment emotivism seemed to have all the answers. However, in 1964 Peter Geach published his version of the "embedding problem," and the stakes rose astronomically. The so-called Frege-Geach problem focused not on the disturbing implications of the linguistic thesis of emotivism, but on its coherence. Briefly, it pointed out that moral utterances don't always stand alone - they can appear in context, and in particular, they can be parts of statements of fact, capable of being true or false. Do they continue in these contexts to be nothing more that expressions of feelings? If so, how can they influence the logical value of such statements of facts? If not, on the other hand, how is moral reasoning possible - to use Geach's example, why should claiming that lying is wrong commit us to believing that it is also wrong to get your brother to lie? There were only two ways out of this dilemma - either to bite the bullet and say that all of what we see as statements of facts are in reality expressions of attitudes (roughly the position espoused by expressionists) or to drop the claim that moral utter- 
ances are expressions of naked emotions, which is what most ethicists did. The project of emotivism was dead.

Is there a larger lesson to be learned from this story? It's worth asking this question because emotions have arguably never been more present in the public discourse. Impressed by their power, we are tempted to see them as distinct, autonomous forces either for bad or for good, and a growing chorus of voices seems to ask not only if we can, but if we should maintain the regime of rationality - maybe it's time we stopped justifying ourselves, and started trusting our feelings?

Karolina Wigura's book Wynalazek nowoczesnego serca [Discovery of a modern heart] can be read as giving a sceptical answer to this question. Following the good tradition of histories of ideas, it cools the enthusiasm of "political emotivists" by reminding them that just like any other notion, our idea of raw, immediate, biologically grounded emotions has its history. Tracing its genealogy is necessary if emotions are to be taken seriously, but it is also potentially destructive - the end result may very well be not so much the purification of the concept, but its deconstruction. On the other hand, by choosing to focus on early modernity as the period in which to search for the philosophical sources of our present understanding of emotions, Wigura lays the ground for a constructive genealogy of feelings. By pointing out the similarities between our present situation and the mental circumstances of our philosophical forefathers, she sketches a guideline for fruitful reflection on and around emotions as we experience and understand them now.

The main thesis of the book is that the roots of what is particular about our present approach to emotions can be traced back to the philosophical work of a handful of exceptional individuals living in the seventeenth century, who proved capable of giving a distinctive and extremely influential voice to the spirit of their times. René Descartes, Thomas Hobbes and Baruch Spinoza, the principal characters in the book, were of course not the only eminent thinkers of the era who were interested in human psychology, but, according to Wigura, they were the ones whose original critique of the classical and scholastic traditions resulted in forging new psychological terminology which we immediately recognise as familiar, even if we have forgotten its original connotations. Wigura's goal is to help us to rediscover its full meaning.

Her strategy is to analyse the writing of the three philosophers in order to reconstruct their respective theories of human emotions. The task is difficult, as none of them made emotions explicitly their point of interest, but 
also because their attitude towards the existing tradition was ambiguous. On the one hand, the philosophers of the seventeenth century acknowledged the unprecedented character of the challenges of their times and were actively seeking a new opening in thinking about human nature and faculties - on the other, they were aware of the hidden potential of the deeper layers of the ideological ground they were standing on, and much of what they proposed came under the guise of reviving ideas silenced or distorted by scholastic philosophy. That's why assessing their particular contribution is impossible unless we first take account of the earlier traditions of thinking about emotions.

Wigura identifies three of these: the classical, the Hellenistic, and the scholastic. Each of them constitutes a step forward in the process of building the language used later by Descartes, Hobbes and Spinoza, but they were in fact far from compatible with each other. The ancient Greeks, who are represented in the book by Plato and Aristotle, talked mostly about passions, phenomena which, whatever their nature, we experience passively, as forces coming from the outside - or from our own bodies, but equally independently of our will. However subtle their actual position on the matter, it is to the classics that we owe the lasting idea of feelings as a problem, a challenge for human beings striving to maintain rational control over their lives. The more optimistic of the two thinkers, Aristotle, believed that passions can be put to work and become essential tools in the quest for a good life, but even he doubted they could be completely domesticated. Hellenistic philosophers, pragmatists that they were, could not accept this vision of a permanently looming conflict and made a distinction between untamed passions, always erroneous and leading reason astray, and calm affects, engendered by reason. The stoic attitude of apatheia was not, therefore, about not experiencing emotions, but about replacing their noxious kind with another, beneficial one, by way of gaining true knowledge about the laws of nature. Since these laws are divine, and since getting to know them is our highest vocation, the affects which come from reason are not just beneficial but moral. This last idea found a continuation in the scholastic theory of emotions. Thomas Aquinas, whose thought Wigura considers to be the highest expression of this tradition, drew on the Aristotelian conception of passions as morally neutral, capable of leading us astray, but also of becoming an important element of virtue - depending on the effort we make to control and educate them. But he also took over from the stoics the idea of affects as something which is not passively experienced, but actively willed; love of God is one example. In this way, Aquinas man- 
aged to propose a complex theory of emotions which at the same time put human beings firmly in the natural order of reality and ascribed to them a transcendental vocation, pointing clearly to their fixed place in the supernatural one.

But it is exactly clarity, suggests Wigura, that the experience of living in the seventeenth century lacked. Describing the extremely complex array of influences and tendencies which decided the character of Early Modernity, she writes that the condition which defined the era was that of self-reliance, which was all too often experienced as solitude. To quote just one of Wigura's examples of this alienating dynamics: the end of the medieval social order gave birth to the courtly culture with its special insistence on the sublimation of emotions - social pressure in this sphere had never been higher. At the same time, religious feelings changed their character to become more personal, but also more private, which made them less and less suited for the role of life anchor. Emotional life got real in a way which made the Aquinian approach obsolete. It required a new kind of guidance to make it work for, and not against, safety, fulfilment and happiness.

As Wigura explains, the most influential thinkers of the seventeenth century turned for this guidance to science, whose tremendous successes at the time could inspire not only trust, but devotion. Descartes is by far the best example. In his late treaty Passions of the Soul he developed a theory of emotions (Wigura credits him with introducing the term in its present meaning; it was next picked up by David Hume) which he himself construed as breaking with tradition, but which largely continued the scholastic ideas, referencing also those of the classical and Hellenistic eras, to make up a heterogeneous whole which few found compelling. The important innovations, apart from the terminological one, were, according to Wigura, Descartes's decision to abandon the distinction between higher and lower emotions, as well as his insistence on treating his inquiries as part of the physiology of the human body. The resulting anthropocentrism had a truly revolutionary potential - even if Descartes followed his predecessors in considering thinking about emotions as a way of cultivating personal virtue. Not so Hobbes, for whom the primary reason for studying passions was the fear of falling pray to their social consequences. As an Epicurean materialist, he saw humans as not essentially different or separate from other beings and from society as a whole. For him, the science of emotions concerned primarily the trappings of the social machine, which he studied in order to make us, its cogs, more resilient. Finally, Spinoza, a follower of the stoics, went further than the other two thinkers in, 
on the one hand, naturalising all aspects of human experience, including rationality, and on the other, spelling out the consequences of the social nature of emotions for the dynamic of their formation and management. Unlike Hobbes, he did not believe that our mutual dependency in society is enough to make emotions the basis of a shared morality - for him, working on your passions could achieve nothing more than personal virtue. But unlike Descartes, who would agree with him so far, he understood this virtue not as setting yourself apart from nature, but as finding your proper place in it.

These innovations may at the first glance seem too piecemeal to amount to a breakthrough in our thinking about emotions. But Wigura points to two profound changes they ushered in: the fading away of the hierarchical vision of the world in which human life found its explanation in its relation to God, and the dawn of scientific anthropocentrism. Together they prepared the ground for nineteenth-century thinkers like William James and Charles Darwin and ultimately paved the way to our present way of thinking about emotions as biologically grounded and morally neutral. Descartes, Hobbes, and Spinoza are largely responsible for our modern reductive, utilitarian interest in human emotions.

Would they be happy with it? That's unlikely, given that for all the research and all our easy familiarity with the subject, emotions continue to cause us trouble. Wigura does not, herself, propose a solution to the problem of the proper place of emotions in our personal and social lives. By turning our attention to the philosophical sources of our ideas about emotions, she does, however, suggest that as we walked the path set for us by Descartes, Hobbes, and Spinoza, we left something precious behind, most of all the idea of a good life as a point of reference for our attitudes towards our own feelings. For the thinkers of the seventeenth century emotions were not external forces or signals from God - but neither were they the raw phenomena that we now often take them to be. They existed and were meaningful in the moral context of a dialogue we conduct with the world and with each other, in search of a life worth living.

Historians of philosophy will appreciate Wigura's endeavour. While the works of each of the thinkers she focuses on have been subject to countless interpretations and reinterpretations, the problem of the seventeenthcentury philosophy of emotions has rarely been systematically addressed. They might, however, question the author's decision not to include Blaise Pascal in her pantheon - his interest in emotions seems to have been even more pronounced than in the case of Descartes, Hobbes and Spinoza, and 
his influence on posterity is hard to overstate. Historians of ideas should not have similar objections; the methodology of Wigura's analysis fully justifies the choice of examples and the story she ultimately tells is credible and compelling.

Can it be put to practical, and especially political use? In some of the interviews published just after the publication of her book, for instance, the one given to Piotr Witwicki (2019) from Rzeczpospolita, Wigura appears to deflect questions about the utility of emotions. On the other hand, in a recent opinion piece written with Jarosław Kuisz for the Guardian, she stresses the urgent need to rekindle "courage, hope and compassion" in our political life (Wigura \& Kuisz 2019). Her point seems to be that we are above all wrong to think about emotions in utilitarian terms - instead, we should recognise both their insurmountable power and their importance for all meaningful acts in our life together. Emotions are hopelessly entangled in the way we perceive reality, understand it and act in it - the effort to separate them, that we've been engaged in at least for the last two hundred years, carries the risk of paralysing social communication and cooperation. But it doesn't mean we're at the mercy of blind forces. The forgotten proposition of the great thinkers of the seventeenth century, which Wigura unearths, is to treat emotions as neither plagues nor tools, but as guides in our difficult quest for living a good life. Perhaps if we approached the emotions rattling our present political life with the same humanistic attitude, we'd have better chances of understanding what we really care about, and how to get it.

Bibliography:

/// Albertson B., Kushner Gadarian S. 2015. Anxious Politics: Democratic Citizenship in a Threatening World, Cambridge University Press.

/// Ayer A. 1936. Language, Truth, and Logic, Oxford University Press.

/// Brader T. 2006. Campaigning for Hearts and Minds: How Emotional Appeals in Political Ads Work, University of Chicago Press.

/// Davies W. 2018. Nervous States: How Feeling Took Over the World, Jonathan Cape.

/// Geach P. 1964. “Assertion,” Philosophical Review, vol. 74, pp. 449-465. 
/// Wigura K. 2019. Wynalazele nowoczesnego serca. Filozoficzne źródła wspótczesnego myślenia o emocjach, Wydawnictwo Naukowe Scholar.

/// Wigura K., Kuisz J. 2019. "Populists Understand the Power of Human Emotion. Europe's Liberals Need to Grasp It, Too," Guardian, 11.12.2019, https://www.theguardian.com/commentisfree/2019/dec/11/populist-politicians-power-emotion-loss-change, accessed 7.02.2020.

/// Witwicki P. 2019. "Karolina Wigura: Trzeba przestać obrażać wyborców PiS," Rzeczpospolita, https://www.rp.pl/Rozmowy-Witwickiego/305309892-Karolina-Wigura-Trzeba-przestac-obrazac-wyborcow-PiS. html, accessed 7.02.2020.

/// Agata Lukomska - assistant professor at the Institute of Philosophy, University of Warsaw. She specialises in ethics (her doctoral thesis took on the ethical thought of Bernard Williams) and her research interests cover meta-ethics, theory of decision and moral psychology.

ORCID: https://orcid.org/0000-0001-5055-1116

Email: agata.lukomska@uw.edu.pl 